\title{
19. PETROLOGY AND GEOCHEMISTRY OF BASALTS AND RELATED ROCKS FROM SITES 214, 215, 216, DSDP LEG 22, INDIAN OCEAN ${ }^{1}$
}

\author{
Geoffrey Thompson and W. B. Bryan, Woods Hole Oceanographic Institution, Woods Hole, Massachusetts \\ and \\ F. A. Frey and C. M. Sung, Department of Earth and Planetary Science, Massachusetts Institute \\ of Technology, Cambridge, Massachusetts
}

\section{INTRODUCTION}

Aspects of the chemistry, petrography, and genesis of eruptive rocks from Sites 214 and 216 on the Ninetyeast Ridge and from Site 215 from the central Indian Ocean basin are discussed. In conjunction with the major element data (Hekinian, Chapter 17) we present additional data for the trace elements $\mathrm{B}, \mathrm{Ba}, \mathrm{Co}, \mathrm{Cr}, \mathrm{Cu}, \mathrm{Ga}, \mathrm{Li}, \mathrm{Mo}, \mathrm{Ni}, \mathrm{Sc}, \mathrm{Sr}$, $\mathrm{U}, \mathrm{V}, \mathrm{Y}, \mathrm{Zr}$ and the lanthanide elements (REE). Petrographic study of the samples confirms the details outlined by Hekinian. Features which are believed to be especially relevant to the interpretation of the geochemical data and to the understanding the origin of the Ninetyeast Ridge are emphasized in this chapter.

Observations and interpretations of the chemical data lead to the suggestion that the volcanic rocks of Sites 214 and 216 on the Ninetyeast Ridge differ in composition, texture, and mineral paragenesis from typical mid-ocean ridge basalts. The petrography and chemistry are consistent with the hypothesis that the Ninetyeast Ridge samples are fractionated lavas which have cooled and crystallized in shallow magma chambers before extrusion. The basalts from Site 215 in the Central Indian Ocean Basin show textures and mineral paragenesis characteristic of deep-sea pillow basalts. However, they are generally more alkaline in character than either the Ninetyeast Ridge basalts or those from the mid-Indian Ocean Ridge.

\section{SITE 215}

\section{Location}

This drill hole is located in the Central Indian Ocean Basin at $8^{\circ} 07.30^{\prime} \mathrm{S}, 84^{\circ} 47.50^{\prime} \mathrm{E}$. Water depth is 5319 meters; approximately 25 meters of basalt were penetrated beneath 151 meters of sediment.

\section{Petrography}

The recovered rocks are weathered to moderately fresh basalts and represent a succession of pillow lavas. Chilled margins and glass are common. Plagioclase appears to be the stable liquidus phase as indicated by well formed microphenocrysts. Olivine crystallized for a brief period as skeletal microphenocrysts. Groundmass plagioclase forms a network of randomly oriented skeletal crystals, many showing the typical hollow cores centered on the $a$-axis.

\footnotetext{
${ }^{1}$ Woods Hole contribution No. 3103 .
}

Section zoning is evident in the more calcic cores of the microphenocrysts and in the hollow square shown by sections perpendicular to the $a$-axis of the groundmass grains. Pyroxenes form skeletal, barred intergrowths interstitial to the plagioclase. Magnetite appears only as tiny granules intergrown with pyroxene. Predominance of quench textures suggests that the magma contains a small amount of superheat as might be expected if it had risen rapidly from considerable depths. Thus, crystallization is delayed until the moment of outpouring and quenching.

\section{Chemistry}

Major and trace element analyses for five samples are given in Table 1. The concentrations of $\mathrm{SiO}_{2}(47 \%-50 \%)$, $\mathrm{Al}_{2} \mathrm{O}_{3}(15 \%-17 \%), \mathrm{TiO}_{2}(1.6 \%-1.7 \%)$, and total iron as $\mathrm{FeO}$ (8\%-9\%) are similar to those in abyssal oceanic tholeiitic basalts. The relatively high ferric to ferrous iron ratios and high weight loss on ignition indicate weathering-that is, low temperature alteration with seawater. Typically this alteration also results in increased concentrations of $\mathrm{K}, \mathrm{B}$, and Li (Hart, 1971; Thompson and Melson, 1970). The sample with the highest water content (ignition loss), J51, has the highest $\mathrm{K}$ and $\mathrm{Li}$ concentrations. We have no major element data for the glass from Core 18, Section 3 in Table 1. It differs from the other basalts in the relatively high concentrations of $\mathrm{Ba}$ and $\mathrm{Sr}$; we have typically found high $\mathrm{Ba}$ and $\mathrm{Sr}$ concentrations in those oceanic basalt glasses that have been palagonitized.

\section{Comparison with Other Oceanic Rocks}

Analyses of the Site 215 basalts with those from other oceanic regions are compared in Table 2. The Site 215 basalts differ from mid-ocean ridge basalts in their much higher concentrations of $\mathrm{K}_{2} \mathrm{O}, \mathrm{P}_{2} \mathrm{O}_{5}, \mathrm{Ba}, \mathrm{Sr}$, and $\mathrm{Zr}$ and their lower concentrations of $\mathrm{Mg}, \mathrm{Ca}, \mathrm{Cr}, \mathrm{Ni}$, and $\mathrm{V}$. Although some potassium enrichment is a result of alteration phenomena, we believe that the high potassium abundance is a primary feature of these basalts. This conclusion results from the significantly different abundance data for trace elements which are less susceptible than potassium to alteration effects, e.g., $\mathrm{Ba}, \mathrm{Sr}, \mathrm{Zr}$ (Cann, 1970) and the observation that despite being more intensely altered the Site 214 basalts (4\%-7\% ignition loss, Table 3) have much lower potassium contents. We conclude that the basaltic magma at Site 215 had a chemical composition distinctly more "alkaline" than basalts typical of active mid-ocean ridges. Although more alkaline than mid-ocean ridge basalts, they are also clearly different in composition from the alkali basalts of oceanic regions (see Table 2). In 
TABLE 1

Analyses of Basalts from Central Indian Ocean Basin, Site 215

\begin{tabular}{|c|c|c|c|c|c|}
\hline $\begin{array}{l}\text { Core-Section } \\
\text { Depth in Core }(\mathrm{cm}) \\
\text { Lab No. }\end{array}$ & $\begin{array}{c}18-2 \\
106-110 \\
\text { J51 }\end{array}$ & $\begin{array}{c}18-3 \\
110-112 \\
\mathrm{~J} 52\end{array}$ & $\begin{array}{l}19-1 \\
23-32 \\
\text { J53 }\end{array}$ & $\begin{array}{l}20-2 \\
20-23 \\
\text { J56 }\end{array}$ & $\begin{array}{l}18-3 \\
26-35 \\
\text { Glass }\end{array}$ \\
\hline $\mathrm{SiO}_{2}$ & 46.40 & 49.68 & 50.23 & 48.29 & \\
\hline $\mathrm{Al}_{2} \mathrm{O}_{3}$ & 15.76 & 16.51 & 16.58 & 16.21 & \\
\hline $\mathrm{Fe}_{2} \mathrm{O}_{3}$ & $8.50^{\mathrm{a}}$ & 2.59 & 2.72 & 2.54 & \\
\hline $\mathrm{FeO}$ & & 5.63 & 5.69 & 5.77 & \\
\hline $\mathrm{MgO}$ & 6.76 & 6.82 & 6.47 & 6.48 & \\
\hline $\mathrm{CaO}$ & 10.64 & 10.52 & 10.39 & 10.24 & \\
\hline $\mathrm{Na}_{2} \mathrm{O}$ & & 2.87 & 3.00 & 2.95 & \\
\hline $\mathrm{K}_{2} \mathrm{O}$ & 0.92 & 0.83 & 0.84 & 0.88 & \\
\hline $\mathrm{TiO}_{2}$ & 1.65 & 1.63 & 1.66 & 1.67 & \\
\hline $\mathrm{P}_{2} \mathrm{O}_{5}$ & & 0.28 & 0.29 & 0.30 & \\
\hline Ignition loss & 3.04 & 2.59 & 2.74 & 2.63 & \\
\hline B & 5 & $<2$ & 4 & 5 & $<2$ \\
\hline $\mathrm{Ba}$ & 495 & 430 & 410 & 450 & 800 \\
\hline Co & 43 & 53 & 43 & 50 & 44 \\
\hline $\mathrm{Cr}$ & 260 & 265 & 265 & 270 & 315 \\
\hline $\mathrm{Cu}$ & 65 & 70 & 65 & 55 & 65 \\
\hline $\mathrm{Ga}$ & 18 & 18 & 18 & 15 & 18 \\
\hline $\mathrm{Li}$ & 28 & 8 & 8 & 9 & 8 \\
\hline Mo & 5 & 6 & 4 & 4 & $<2$ \\
\hline $\mathrm{Ni}$ & 100 & 105 & 95 & 100 & 100 \\
\hline $\mathrm{Sr}$ & 515 & 380 & 320 & 360 & 750 \\
\hline $\mathrm{U}^{\mathrm{b}}$ & 0.5 & 0.3 & 0.4 & 0.4 & 0.4 \\
\hline V & 245 & 245 & 255 & 260 & 260 \\
\hline Y & 35 & 38 & 35 & 36 & 42 \\
\hline $\mathrm{Zr}$ & 170 & 160 & 160 & 155 & 135 \\
\hline
\end{tabular}

Note: Major elements in percent weight; analyses by X-ray fluorescence taken from Hekenian (Chapter 17). Trace elements in ppm; analyses by emission spectrometry. See Thompson and Bankston (1969) for details on precision and accuracy.

atotal $\mathrm{Fe}$ as $\mathrm{FeO}$.

bAnalyzed by fission track technique (Fisher, 1970).

particular the Site 215 basalts have higher concentrations of $\mathrm{Mg}, \mathrm{Ca}, \mathrm{Co}, \mathrm{Cr}$, and $\mathrm{Ni}$ and lower concentrations of $\mathrm{K}, \mathrm{P}$, $\mathrm{Ba}, \mathrm{Sr}, \mathrm{Y}$, and $\mathrm{Zr}$ than the alkali basalts.

Although Site 215 is close to the Ninetyeast Ridge, the basalts are clearly different in composition from those at Site 214 (see Tables 2 and 3). Trace element data for the basalt from the East Indian Ocean Basin (Site 213) are not available, but the major element data for this basalt compare well with those for Site 215 (Chapter 17).

\section{SITES 214 AND 216}

\section{Location}

Sites 214 and 216 are located on the Ninetyeast Ridge at $11^{\circ} 20.21^{\prime} \mathrm{S}, \quad 88^{\circ} 43.08^{\prime} \mathrm{E}$ and $1^{\circ} 27.73^{\prime} \mathrm{N}, 90^{\circ} 12.48^{\prime} \mathrm{E}$, respectively. Water depth at Site 214 is 1665 meters, and approximately 56 meters of basement were penetrated beneath 440 meters of sediment. At Site 216 water depth is 2247 meters, and 27.5 meters of basement were penetrated beneath 457 meters of sediment.

\section{Petrography}

Basalts recovered at both sites were often vesicular and amygdaloidal. The upper portion of the igneous rocks at Site 214 (Cores 48 to 51) was composed of pilotaxitic trachytic-textured rocks differing in composition from the lower basalts. Only basalts were recovered at Site 216 . However, all of the Site 214 and 216 lavas are similar in their textures and mineral paragenesis in spite of the contrasts in composition. The principal minerals are plagioclase, pyroxene, and magnetite. Apparently bulk compositional differences must be due to subtle variations in composition and proportions of these mineral phases. Difference in degree of alteration is a complicating factor; in general, the upper, more siliceous lavas of Site 214 are less altered than the lower basalts here and at Site 216.

Plagioclase and magnetite are the prominent phenocryst or microphenocryst phases in these lavas. Pyroxene does occur in minor amounts as coarser granules associated with the plagioclase and magnetite as noted by Hekinian (Chapter 17). Pyroxene and especially magnetite are very rare as phenocryst (liquidus) phases in ocean ridge basalts. Much of the magnetite has been marginally oxidized, but overall the relatively large subhedral crystals appear to be of primary magmatic origin and closely follow the precipitation of plagioclase and pyroxene. This suggests that the high total iron concentration in these lavas is a primary magmatic feature, although the relatively high ferric to ferrous iron ratio may have been enhanced by later oxidation. There is no evidence that olivine has ever crystallized in the Site 214 and 216 rocks, as its presence is not even indicated by crystal pseudomorphs.

The trachytic texture of the groundmass in these lavas is also typical. It implies that a considerable amount of crystalline material was in suspension in the liquid at the time of extrusion. This in turn implies that magmatic temperatures were at or below the liquidus. In contrast, typical ocean ridge pillow basalts show a predominance of randomly oriented groundmass minerals displaying delicate quench textures as described by Bryan (1972) and seen in the basalts of Site 215 . Such delicate features could not survive shearing stresses produced by flow. Thus, the textures suggest that the Ninetyeast Ridge lavas reached thermal and chemical equilibrium in relatively shallow magma chambers.

\section{Chemistry}

Major and trace element analyses of the basalts from the lower part of Site 214 and the basalts from Site 216 are given in Table 3. Hekinian has divided the basalts of Site 214 into two groups-nonvesicular (Core 53 and Core 54, Section 2) and vesicular (Core 54, Section 3). No significant compositional differences between these two groups was found. However, within the basalts of Sites 214 and 216 a range of compositions that was believed to reflect both alteration and differentiation processes was noted. 
TABLE 2

Comparative Analyses of Basalts from Site 215 and Those from Other Oceanic Regions

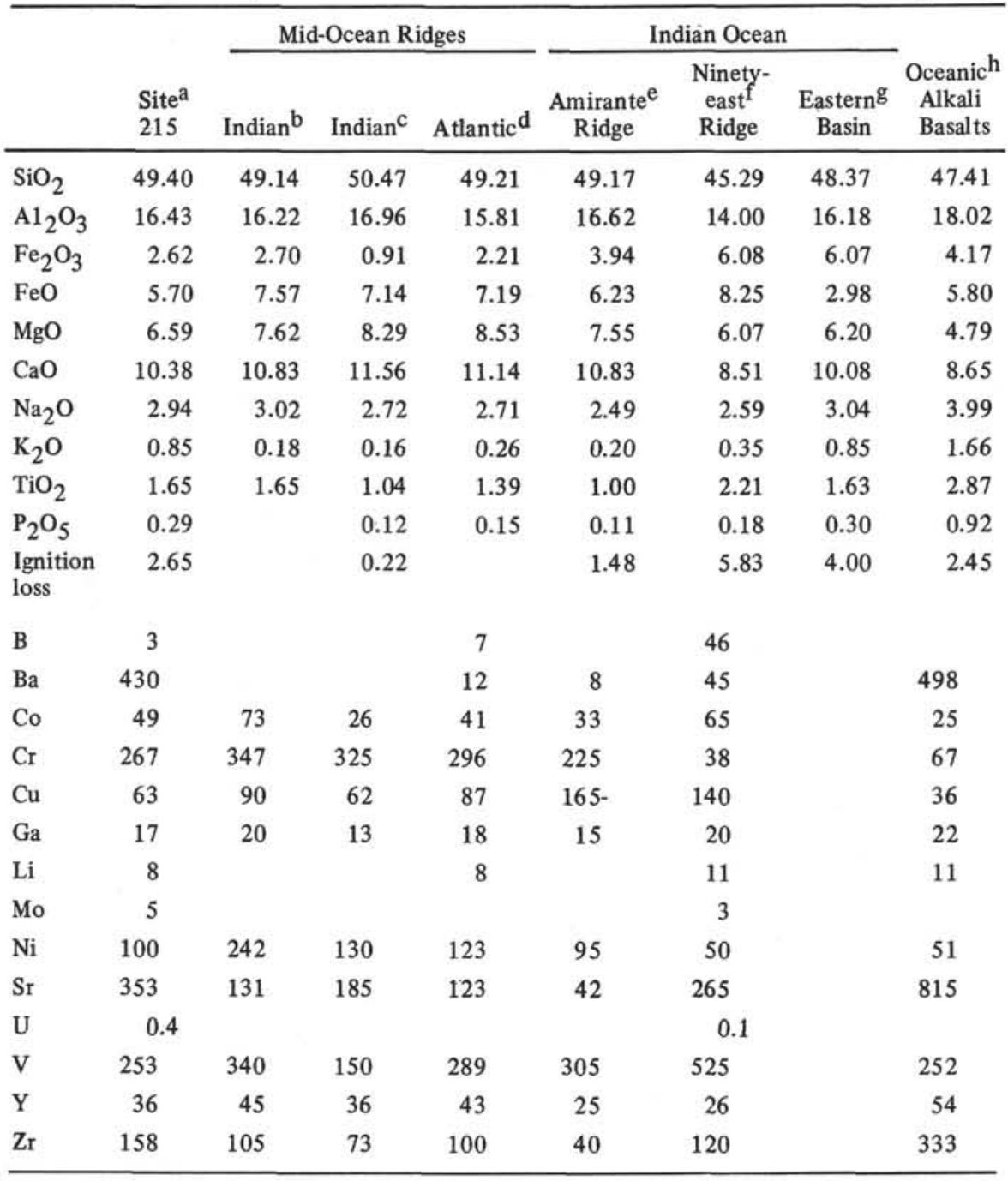

${ }^{a}$ Average J52, 53, 56 for major elements, J51, 52, 53, 56 for trace elements (see Table 1).

${ }^{b}$ Average 6 basalts from Carlsberg Ridge, from Cann (1969).

${ }^{c}$ Average 2 basalts from Mid-Indian Ocean ridge, from Engel and Fisher (1969).

d Average 33 basalts from Mid-Atlantic Ridge, from Melson and Thompson (1971).

eAverage 3 basalts from Amirante Ridge, from Fisher et al. (1968).

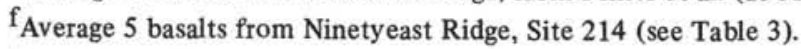

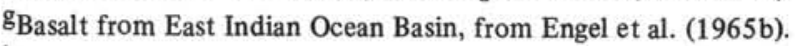

h Average 10 oceanic alkali basalts, from Engel et al. (1965a).

\section{Alteration Effects}

The most obvious indicators of alteration are high weight loss on ignition and the extensive oxidation of iron. Those samples with the largest water content (ignition loss) also contain the highest concentrations of $\mathrm{B}$ and $\mathrm{Li}$. Within the basalts the correlation of alteration with $\mathrm{Li}$ is fairly good and better than that with $\mathrm{B}$. This may be due to some hydrothermal alteration as well as halmyrolysis; the former would tend to leach out boron (Thompson and Melson, 1970). In these particular samples there is no increase in U content with increasing degree of alteration, contrary to the observations made by Aumento (1971). In fact there may well be a negative correlation of $U$ concentration with degree of alteration. Alteration also increases the alkali contents of basalts (Hart, 1969). However, these particular samples contain secondary smectites and calcite in the amygdales and vesicle walls (see Hekinian's descriptions, Chapter 17). These minerals would increase the $\mathrm{K}, \mathrm{Mg}$, and $\mathrm{Sr}$ concentrations (Thompson, 1972; Melson and Thompson, 1973).

\section{Differentiation Effects}

Differences attributable to fractional crystallization can be distinguished from alteration effects if one utilizes trace 
TABLE 3

Analyses of Basalts from Sites 214 and 216, Ninetyeast Ridge

\begin{tabular}{|c|c|c|c|c|c|c|c|c|c|c|c|c|c|}
\hline \multirow[b]{2}{*}{ Core-Section } & \multicolumn{6}{|c|}{ Site 214} & \multicolumn{7}{|c|}{ Site 216} \\
\hline & $53-1$ & $53-1$ & $54-2$ & $54-2$ & $54-3$ & $54-3$ & $36-4$ & $37-1$ & $37-2$ & $37-3$ & $38-1$ & 38 & $38-4$ \\
\hline Depth in Core $(\mathrm{cm})$ & $26-30$ & $97-100$ & $28-30$ & $117-127$ & $0-4$ & $42-50$ & $33-40$ & $98-104$ & $80-87$ & $85-90$ & $117-122$ & $\mathrm{cc}$ & $80-86$ \\
\hline Lab No. & $\mathrm{J} 42$ & $\mathrm{~J} 44$ & $\mathrm{~J} 45$ & J46 & $\mathrm{J} 47$ & $\mathrm{~J} 48$ & $\mathrm{~J} 22$ & $\mathrm{~J} 23$ & $\mathrm{~J} 25$ & J26 & J27 & $\mathrm{J} 30$ & $\mathrm{~J} 32$ \\
\hline $\mathrm{SiO}_{2}$ & 45.50 & 43.96 & 47.71 & 45.32 & 43.94 & & & 45.76 & 48.14 & 48.07 & & 48.67 & \\
\hline $\mathrm{Al}_{2} \mathrm{O}_{3}$ & 14.70 & 13.51 & 13.47 & 14.70 & 13.65 & & & 13.07 & 13.00 & 13.22 & & 12.63 & \\
\hline $\mathrm{Fe}_{2} \mathrm{O}_{3}$ & 6.82 & 5.99 & 5.21 & 5.31 & 7.09 & & & 6.49 & 6.46 & 5.41 & & 6.04 & \\
\hline $\mathrm{FeO}$ & 7.69 & 8.96 & 8.00 & 8.00 & 8.61 & & & 8.00 & 8.00 & 8.00 & & 7.15 & \\
\hline $\mathrm{MgO}$ & 6.22 & 6.59 & 5.87 & 5.59 & 6.07 & & & 6.22 & 5.67 & 6.85 & & 6.55 & \\
\hline $\mathrm{CaO}$ & 8.88 & 8.37 & 9.98 & 8.50 & 6.84 & & & 8.16 & 9.18 & 7.42 & & 9.10 & \\
\hline $\mathrm{Na}_{2} \mathrm{O}$ & 2.40 & 2.28 & 2.60 & 2.73 & 2.95 & & & 2.53 & 2.41 & 2.63 & & 2.30 & \\
\hline $\mathrm{K}_{2} \mathrm{O}$ & 0.21 & 0.30 & 0.18 & 0.81 & 0.26 & & & 1.29 & 0.73 & 0.57 & & 0.90 & \\
\hline $\mathrm{TiO}_{2}$ & 2.12 & 2.03 & 2.25 & 2.14 & 2.50 & & & 2.71 & 2.65 & 2.76 & & 2.50 & \\
\hline $\mathrm{P}_{2} \mathrm{O}_{5}$ & 0.17 & 0.16 & 0.18 & 0.18 & 0.21 & & & 0.22 & 0.21 & 0.21 & & 0.19 & \\
\hline Ignition loss & 5.80 & 7.16 & 4.31 & 5.28 & 6.62 & & & 4.26 & 2.29 & 4.90 & & 3.71 & \\
\hline B & 40 & 200 & $<2$ & 6 & 20 & 10 & 5 & 8 & 3 & $<2$ & 2 & 4 & 2 \\
\hline $\mathrm{Ba}$ & 22 & 28 & 70 & 55 & 60 & 35 & 230 & 155 & 105 & 95 & 115 & 100 & 180 \\
\hline $\mathrm{Co}$ & 57 & 78 & 61 & 49 & 80 & 66 & 62 & 50 & 50 & 53 & 56 & 47 & 52 \\
\hline $\mathrm{Cr}$ & 40 & 50 & 30 & 40 & 35 & 30 & 165 & 25 & 20 & 20 & 22 & 25 & 35 \\
\hline $\mathrm{Cu}$ & 50 & 140 & 185 & 175 & 160 & 125 & 110 & 55 & 80 & 210 & 60 & 70 & 85 \\
\hline $\mathrm{Ga}$ & 19 & 18 & 20 & 21 & 20 & 20 & 22 & 21 & 17 & 20 & 17 & 19 & 20 \\
\hline $\mathrm{Li}$ & 13 & 25 & 6 & 8 & 5 & 6 & 28 & 66 & 6 & 12 & 6 & 11 & 13 \\
\hline Mo & $<2$ & 3 & 7 & 4 & 2 & 4 & 3 & 5 & 7 & 6 & 6 & 8 & 5 \\
\hline $\mathrm{Ni}$ & 55 & 60 & 45 & 45 & 50 & 45 & 65 & 40 & 35 & 40 & 35 & 45 & 45 \\
\hline $\mathrm{Sr}$ & 165 & 185 & 150 & 355 & 365 & 370 & 610 & 220 & 145 & 115 & 150 & 170 & 240 \\
\hline V & 450 & 580 & 430 & 450 & 680 & 555 & 415 & 540 & 415 & 455 & 470 & 395 & 415 \\
\hline $\mathrm{Y}$ & 27 & 13 & 40 & 35 & 15 & 24 & 26 & 31 & 27 & 28 & 32 & 37 & 35 \\
\hline $\mathrm{Zr}$ & 110 & 95 & 160 & 145 & 105 & 110 & 135 & 155 & 150 & 175 & 150 & 180 & 170 \\
\hline $\mathrm{U}^{\mathrm{a}}$ & 0.1 & 0.04 & 0.1 & 0.1 & 0.07 & 0.2 & 0.1 & 0.3 & 1.0 & 0.2 & 0.3 & 0.2 & 0.1 \\
\hline $\mathrm{Sc}^{\mathrm{b}}$ & 45 & & & 45 & & & & & & & & & \\
\hline $\mathrm{Hf}^{\mathrm{b}}$ & 4 & & & 4.2 & & & & & & & & & \\
\hline $\mathrm{Ta}^{\mathrm{b}}$ & 1.4 & & & 2.8 & & & & & & & & & \\
\hline $\mathrm{La}^{\mathrm{b}}$ & 6.6 & & & 8.9 & & & & & & & & & \\
\hline $\mathrm{Cd}^{\mathrm{b}}$ & 20.3 & & & 22.5 & & & & & & & & & \\
\hline $\mathrm{Nd}^{\mathrm{b}}$ & 14.3 & & & 15.1 & & & & & & & & & \\
\hline $\mathrm{Sm}^{\mathrm{b}}$ & 5.1 & & & 4.9 & & & & & & & & & \\
\hline $\mathrm{Eu}^{\mathrm{b}}$ & 1.7 & & & 1.8 & & & & & & & & & \\
\hline $\mathrm{Tb}^{\mathrm{b}}$ & 0.8 & & & 0.9 & & & & & & & & & \\
\hline $\mathrm{Yb}^{\mathrm{b}}$ & 2.4 & & & 2.6 & & & & & & & & & \\
\hline $\mathrm{Lu}^{\mathrm{b}}$ & 0.4 & & & 0.4 & & & & & & & & & \\
\hline
\end{tabular}

Note: See note, Table 1.

${ }^{\mathrm{a}}$ Analyzed by fission track technique.

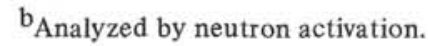


element correlations which are believed to be unaffected by weathering. Within the basalts of Site 214 the increasing concentrations of $\mathrm{Ba}, \mathrm{Y}, \mathrm{Zr}, \mathrm{Ti}$, and $\mathrm{P}$ are correlated with decreasing concentrations of $\mathrm{Cr}, \mathrm{Co}, \mathrm{Ni}, \mathrm{V}$, and $\mathrm{Mg}$. Samples J44 and 47 are the least fractionated and Samples $\mathrm{J} 45$ and 46 are the most fractionated (Figure 1). The basalts of Site 216 are more closely grouped in composition, but the same trend can be recognized with $\mathrm{J} 30$ as the most fractionated (high concentrations of $\mathrm{Y}$ and $\mathrm{Zr}$ ). The relatively high concentrations of $\mathrm{K}, \mathrm{Ba}, \mathrm{Y}$, and $\mathrm{Zr}$ and low concentrations of $\mathrm{Co}, \mathrm{Ni}$, and $\mathrm{V}$ in the Site 216 basalts compared with those at Site 214 indicate them to be slightly more differentiated. This is shown in Figure 1 where the average Site 216 basalt falls at the highly differentiated end of the trends.

\section{Comparison with Other Rock Types}

In Table 4 chemical analyses of the Site 214 and 216 basalts with those from other oceanic regions are compared. Although the Ninetyeast Ridge basalts are altered, much of their present chemical characteristics (particularly if recalculated on a water and $\mathrm{CO}_{2}$-free basis) reflect the original magma composition. The Ninetyeast Ridge basalts are lower in $\mathrm{Ca}, \mathrm{Mg}, \mathrm{Cr}$, and $\mathrm{Ni}$ concentrations and higher in $\mathrm{Fe}, \mathrm{Ti}, \mathrm{K}, \mathrm{Ba}, \mathrm{Cu}, \mathrm{Sr}, \mathrm{V}$, and $\mathrm{Zr}$ concentrations that mid-ocean ridge basalts. Compared to basalts from Reunion Island in the Indian Ocean, the Ninetyeast Ridge basalts are higher in $\mathrm{Fe}$ and $\mathrm{V}$ concentrations but lower in $\mathrm{Ca}, \mathrm{K}, \mathrm{Ba}$, $\mathrm{Cr}, \mathrm{Ni}$, and $\mathrm{Sr}$ concentrations. Compared to basalt from the Tonga Islands (which are also on a long linear ridge), the Ninetyeast Ridge basalts have higher concentrations of $\mathrm{Fe}$, $\mathrm{Na}, \mathrm{K}, \mathrm{Ti}, \mathrm{P}, \mathrm{Ba}, \mathrm{Co}, \mathrm{Cu}, \mathrm{Ni}, \mathrm{Sr}, \mathrm{V}, \mathrm{Y}$, and $\mathrm{Zr}$ and lower concentrations of $\mathrm{Al}, \mathrm{Ca}$, and $\mathrm{Cr}$.

The basalts from Sites 214 and 216 are chemically similar to Icelandic tholeiitic basalts, particularly those from the Veidivötn region. In fact the Ninetyeast Ridge basalts differ from mid-Indian Ocean Ridge basalts in the same ways chemically that Jakobsson (1972) concluded Icelandic tholeiitic basalts differed from mid-Atlantic Ridge basalts in that, "Icelandic basalts are distinctly higher in $\mathrm{Fe}$, $\mathrm{Ti}, \mathrm{K}$ with lower $\mathrm{Al}, \mathrm{Mg}$ and $\mathrm{Na} / \mathrm{K}$ ratios." Also in Figure 2 the REE distributions are shown, relative to chondrites, for Site 214, Icelandic and Oceanic basalts. Normal mid-ocean ridge basalts are typically depleted in the light REE, while basalts from Site 214 are slightly enriched in these elements and have a very similar distribution and total REE content to tholeiitic basalts from Iceland.

\section{Oceanic Andesites-Site 214}

The upper lavas of Site 214 (Cores 48 to 51) differ compositionally from the lower basalts. Major and trace element analyses of these upper lavas are given in Table 5. They are characterized by high $\mathrm{SiO}_{2}(54 \%-58 \%), \mathrm{Al}_{2} \mathrm{O}_{3}$ $(15 \%-16 \%)$, total iron as $\mathrm{FeO}(<11 \%), \mathrm{Na}_{2} \mathrm{O}(>3 \%-5 \%)$, and $\mathrm{K}_{2} \mathrm{O}(>1 \%)$ and low $\mathrm{MgO}(<3 \%), \mathrm{CaO}(<6 \%)$, and $\mathrm{TiO}_{2}(<1 \%-5 \%)$. Hekinian has called these rocks intermediate differentiated rocks or oceanic andesites-the latter term is used here.

These andesites are much less altered than the basalts from the same site. Ignition loss, iron oxidation, and B and Li concentrations are generally lower. The sample with the greatest ignition loss, $\mathrm{J} 41$, has the greatest $\mathrm{Li}$ concentration. Secondary minerals are also present in the vesicles, particularly calcite. Sample J41 has the highest $\mathrm{Ca}$ and $\mathrm{Sr}$ concentration attributable to the presence of a calcite vein.

Compositionally there is little variation within the group, although J41 appears to be the most differentiated (high $\mathrm{Ba}, \mathrm{Y}, \mathrm{Zr}$, and $\mathrm{P}$, with low $\mathrm{Co}$ and $\mathrm{Mg}$ abundances). The variations of $\mathrm{Ba}, \mathrm{Y}, \mathrm{Zr}, \mathrm{P}$, and $\mathrm{Co}$ in these oceanic andesites follow the same trend as in the basalts and the data are consistent with a process in which the basalts are parent magmas for the oceanic andesites. The close association in space and time (little sedimentation between flows) also supports a genetic relationship.

In Table 6 analyses of the Site 214 andesites with andesites or similar rocks from other oceanic regions are compared. Compared to the Tonga Island arc andesites, the Ninetyeast Ridge andesites have lower concentrations of $\mathrm{Ca}, \mathrm{Fe}, \mathrm{Mg}, \mathrm{Cr}, \mathrm{Cu}, \mathrm{Ni}$, and $\mathrm{V}$ and have higher concentrations of $\mathrm{Na}, \mathrm{K}, \mathrm{Ti}, \mathrm{P}, \mathrm{Ba}, \mathrm{Sr}$, and $\mathrm{Zr}$. The Ninetyeast Ridge andesites have lower $\mathrm{Fe}$ concentrations than their parent basalts which is contrary to the Tonga andesites. A similar comparison can be made with the average circum-Pacific andesite computed by Taylor et al. (1969). Compared to the mugearites of Reunion Island in the Indian Ocean, the Ninetyeast Ridge andesites have lower concentrations of $\mathrm{Ti}$, $\mathrm{Na}, \mathrm{K}, \mathrm{Ba}, \mathrm{Zr}$, and $\mathrm{V}$.

Because the Ninetyeast Ridge basalts are similar in composition to Icelandic tholeiitic basalts and because a similar association of basalts and andesites occurs in Iceland (Thorarinsson, 1967; Jakobsson, 1972), analyses of andesites from Hekla, a volcano in the neovolcanic zone of Iceland, are shown. The similarity of these andesites to those of the Ninetyeast Ridge, particularly in major element composition, is evident in Table 6. The slopes of the REE distribution patterns (Figure 2) are also very similar. Neither the Ninetyeast Ridge andesites nor the Hakla andesites have REE abundances like calc-alkali andesites (Ewart et al., in press).

Some compositional differences between the Hekla and Ninetyeast Ridge andesites, e.g., the higher REE and $\mathrm{Zr}$ concentrations in Hekla samples were noted. Jakobsson (1972) has indicated that Hekla andesites may be derived from transitional Icelandic tholeiites which are slightly more alkaline than normal Icelandic tholeiites-those most closely comparable to the Ninetyeast Ridge basalts (see Table 4). Thus, the compositional differences between the Hekla and Ninetyeast Ridge andesites are consistent with slight compositional differences in their respective parent basalts. Nevertheless, the chemical similarity of these two andesitic suites is suggestive of a similar origin.

\section{Origin of the Ninetyeast Ridge}

The basalts and andesites from the Ninetyeast Ridge differ in texture, mineralogy, and chemistry from rocks extruded at spreading centers along mid-ocean ridges and from those found on the floors of the Indian Ocean basins. They also differ markedly in composition from lavas extruded in island arcs. Thus the Ninetyeast Ridge probably does not represent an old, previously active mid-ocean ridge and site of sea-floor spreading nor does it appear to be an island arc-type of structure. 

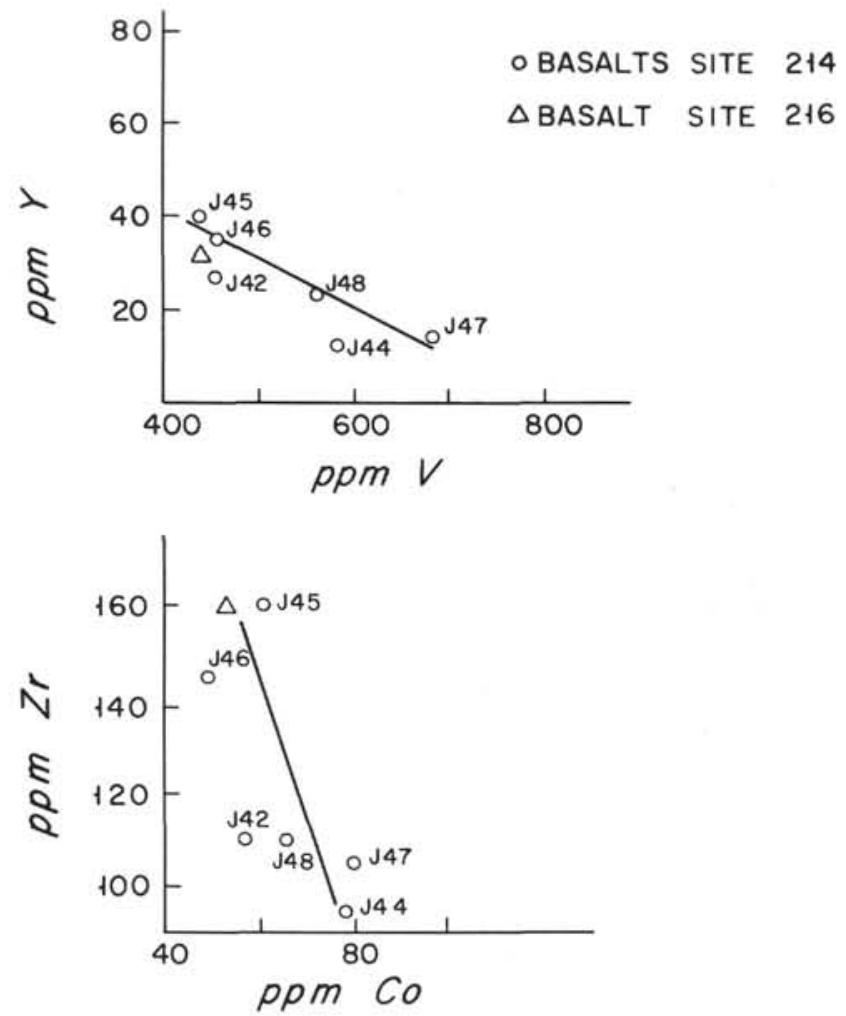

Figure 1. Differentiation trends in the Site 214 basalts as indicated by the negative correlation of $Y$ with $\mathrm{V}$ and $\mathrm{Zr}$ with Co. Circles represent Site 214 basalts, individual sample numbers are shown. The triangle represents the average composition of Site 216 basalts.

Because of the similarity in mineralogy and chemical composition between basalts and andesites of the Iceland Plateau and Ninetyeast Ridge, a similar derivation is suggested. The Iceland Platform is presumed to represent the surface expression of a "hot-spot" or plume of molten material derived from deep in the mantle (Schilling, in press). Such a hypothesis for the Ninetyeast Ridge would lead to difficulties in explaining the linearity and present inactivity of the ridge and would require a change in the spreading rate of the Indian plate to be consistent with the hypotheses presented in the Regional Synthesis (Chapter 41).

The shipboard scientists conclude that the northern part of the Ninetyeast Ridge (e.g., Site 216) could be formed by passage of the Indian plate over a magma chamber. However, they argue that the southern part of the ridge (e.g., Site 214) may be better explained as a leaky transform fault (Chapter 41). Studies of such transform faults in the Atlantic (Thompson and Melson, 1972) indicate the eruptive rocks to be different from normal mid-ocean ridge basalts and more alkaline than the basalts of the Ninetyeast Ridge. Our data further indicate that the basalts at Site 214 are very similar in texture, mineralogy, and composition to those at Site 216, implying similar origins. It is suggested that the fractionated lavas of the Ninetyeast Ridge may represent the surface expression of a former mantle plume with consequent uplift of the lithosphere as it moved over the hot spot.
Hekinian has suggested that the Ninetyeast Ridge lavas are similar in composition to those found on St. Paul and New Amsterdam islands in the Indian Ocean. There are not enough data, particularly on trace element compositions, to make a thorough comparison. It would imply that these islands may be an extension of the Ninetyeast Ridge to the south, although they do appear to be offset from the main strike of the ridge.

\section{ACKNOWLEDGMENTS}

We thank Roger Hekinian for supplying the samples and giving us access to his major element data and thin sections. This work was supported by NSF Grant GA31244.

\section{REFERENCES}

Aumento, F., 1971. Uranium content of mid-oceanic basalts: Earth Planet. Sci. Lett., v. 11, p. 90-94.

Bryan, W. B., 1972. Morphology of quench crystals in submarine basalts: J. Geophys. Res., v. 77, p. 5812-5819.

Bryan, W. B., Stice, G. D., and Ewart, A., 1972. Geology, petrography, and geochemistry of the volcanic islands of Tonga: J. Geophys. Res., v. 77, p. 1566-1585.

Cann, J. R., 1969. Spilites from the Carlsberg Ridge, Indian Ocean. J. Petrology, v. 10, p. 1-19.

1970. Rb, Sr, Y, Zr, $\mathrm{Nb}$ in some ocean floor basaltic rocks: Earth Planet. Sci. Lett., v. 10, p. 7-11.

Engel, A. E. J., Engel, C. G., and Havens, R. G., 1965a. Chemical characteristics of oceanic basalts and the upper mantle: Geol. Soc. Am. Bull., v. 76, p. 719-734.

Engel, C. G., Fisher, R. L., and Engel, A. E. J., 1965b. Igneous rocks of the Indian Ocean floor: Science, v. 150, p. 605-609.

Engel, C. G. and Fisher, R. L., 1969. Lherzolite, anorthosite, gabbro and basalt dredged from the mid-Indian Ocean Ridge: Science, v. 166, p. 1136-1141.

Ewart, A., Bryan, W. B., and Gill, J., in press. Mineralogy and geochemistry of the younger volcanic islands of Tonga, Southwest Pacific: J. Petrology.

Fisher, D. E., 1970. Homogenized fission track determination of uranium in whole rock geologic samples: Anal. Chem., v. 42, p. 414-416.

Fisher, R. L., Engel, C. G., and Hilde, T. W. C., 1968. Basalts dredged from the Amirante Ridge, western Indian Ocean: Deep-Sea Res., v. 15, p. 521-534.

Hart, S. R., 1969. K, Rb, Cs contents and K/Rb, K/Cs ratios of fresh and altered submarine basalts: Earth Planet. Sci. Lett., v. 6, p. 295-303.

, 1971. K, Rb, Cs, $\mathrm{Sr}$ and $\mathrm{Ba}$ contents and $\mathrm{Sr}$ isotope ratios of ocean floor basalts: Phil. Trans. Roy. Soc. Lond. A, v. 268, p. 573-587.

Haskin, L. A., Helmke, P. A., Paster, T. P., and Allen, R. O., 1971. Rare earths in meteoritic, terrestrial and lunar materials: In Activation analysis in geochemistry and cosmochemistry, Brunfelt, A. O. (Ed.), E. Steinnes. Proc. NATO Advanced Studies Institute, Norway (Scand. Univ. Books), p. 201-208.

Jakobsson, S. P., 1972. Chemistry and distribution pattern of Recent basaltic rocks in Iceland: Lithos, v. 5, p. 365-386.

Melson, W. G., and Thompson, G., 1971. Petrology of a transform fault zone and adjacent ridge segments: Phil. Trans. Roy. Soc. Lond. A, v. 268, p. 423-441. 
TABLE 4

Comparative Analyses of Basalts from Site 214 and 216, Ninetyeast Ridge and Those from Other Oceanic Regions

\begin{tabular}{|c|c|c|c|c|c|c|c|c|c|}
\hline & & & $\underset{\text { Indian }}{\text { Mid- }}$ & & & Tonga $f$ & Icelandic & Tholeiites & $\begin{array}{l}\text { Icelandic } \\
\text { Transitional }\end{array}$ \\
\hline & $\begin{array}{l}\text { Site }^{\mathrm{a}} \\
214\end{array}$ & $\begin{array}{l}\text { Site }^{b} \\
216\end{array}$ & $\begin{array}{l}\text { Ocean } \\
\text { Ridge }\end{array}$ & $\begin{array}{c}\text { Atlantic } \\
\text { Ridge }\end{array}$ & $\begin{array}{l}\text { Reunione } \\
\text { Isiand }\end{array}$ & $\begin{array}{l}\text { Island } \\
\text { Arc }\end{array}$ & $\begin{array}{l}\text { Rekjanesg } \\
\text { Peninsular }\end{array}$ & $\begin{array}{l}\text { Veidivötn } \\
\text { Region }\end{array}$ & $\begin{array}{c}\text { Torfajokull } \\
\text { Region }\end{array}$ \\
\hline $\mathrm{SiO}_{2}$ & 45.29 & 47.66 & 49.14 & 49.21 & 45.99 & 49.19 & 48.01 & 49.51 & 47.00 \\
\hline $\mathrm{Al}_{2} \mathrm{O}_{3}$ & 14.00 & 12.98 & 16.22 & 15.81 & 15.65 & 20.61 & 14.09 & 13.97 & 13.84 \\
\hline $\mathrm{Fe}_{2} \mathrm{O}_{3}$ & 6.08 & 6.10 & 2.70 & 2.21 & 5.95 & 2.93 & 2.69 & 2.15 & 2.74 \\
\hline $\mathrm{FeO}$ & 8.25 & 7.79 & 7.57 & 7.19 & 6.50 & 5.63 & 10.06 & 11.37 & 12.68 \\
\hline $\mathrm{MgO}$ & 6.07 & 6.32 & 7.62 & 8.53 & 7.66 & 5.93 & 8.29 & 5.97 & 5.96 \\
\hline $\mathrm{CaO}$ & 8.51 & 8.46 & 10.83 & 11.14 & 12.60 & 11.78 & 11.77 & 10.76 & 9.74 \\
\hline $\mathrm{Na}_{2} \mathrm{O}$ & 2.59 & 2.47 & 3.02 & 2.71 & 2.39 & 1.21 & 2.17 & 2.71 & 2.98 \\
\hline $\mathrm{K}_{2} \mathrm{O}$ & 0.35 & 0.87 & 0.18 & 0.26 & 0.71 & 0.24 & 0.29 & 0.42 & 0.65 \\
\hline $\mathrm{TiO}_{2}$ & 2.21 & 2.65 & 1.65 & 1.39 & 2.18 & 0.42 & 1.87 & 2.39 & 3.71 \\
\hline $\begin{array}{l}\mathrm{P}_{2} \mathrm{O}_{5} \\
\text { Ignition }\end{array}$ & 0.18 & 0.21 & & 0.15 & 0.32 & 0.04 & 0.19 & 0.23 & 0.33 \\
\hline loss & 5.83 & 3.79 & & & & 2.06 & 0.28 & 0.42 & 0.38 \\
\hline B & 46 & 4 & & 7 & & & & & \\
\hline $\mathrm{Ba}$ & 45 & 140 & & 12 & 310 & 14 & & & \\
\hline Co & 65 & 53 & 73 & 41 & & 30 & & & \\
\hline $\mathrm{Cr}$ & 38 & 45 & 347 & 296 & 110 & 75 & & & \\
\hline $\mathrm{Cu}$ & 140 & 96 & 90 & 87 & & 51 & & & \\
\hline $\mathrm{Ga}$ & 20 & 19 & 20 & 18 & & 13 & & & \\
\hline $\mathrm{Li}$ & 11 & 12 & & 8 & & & & & \\
\hline Mo & 3 & 6 & & & & & & & \\
\hline $\mathrm{Ni}$ & 50 & 44 & 242 & 123 & 120 & 25 & & & \\
\hline $\mathrm{Sr}$ & 265 & 235 & 131 & 123 & 390 & 115 & & & \\
\hline $\mathrm{U}$ & 0.1 & 0.3 & & & & & & & \\
\hline V & 525 & 445 & 340 & 289 & 340 & 230 & & & \\
\hline $\mathrm{Y}$ & 26 & 31 & 45 & 43 & 22 & 12 & & & \\
\hline $\mathrm{Zr}$ & 120 & 159 & 105 & 100 & 125 & 21 & & & \\
\hline $\mathrm{La}$ & 7.7 & & & & & & 8.6 & & \\
\hline $\mathrm{Sm}$ & 4.9 & & & & & & 4.6 & & \\
\hline $\mathrm{Yb}$ & 2.6 & & & & & & 2.7 & & \\
\hline
\end{tabular}

${ }^{\text {a Average }} 6$ basalts from Table 3 .

${ }^{b}$ Average 7 basalts from Table 3 .

$\mathrm{c}_{\text {Average }} 6$ basalts from Carlsberg Ridge, from Cann (1969). See also other tabulations in Table 2.

dAverage 33 basalts from Mid-Atlantic Ridge, from Melson and Thompson (1971).

e Average basalt, Reunion Island, Re 512G groundmass, from Upton and Wadsworth (1972).

${ }^{f}$ Basalt, Eua Island (111549-7), from Bryan et al. (1972).

g Average 12 basalts, Rekjanes Peninsula, from Jakobsson (1972); lanthanide elements from Rekjanes peninsula, from Schilling (in press).

${ }^{h}$ Average 11 basalts, Veidivötn Region, from Jakobsson (1972).

${ }^{\mathrm{i}}$ Average 9 basalts, Torfajökull Region, from Jakobsson (1972). 


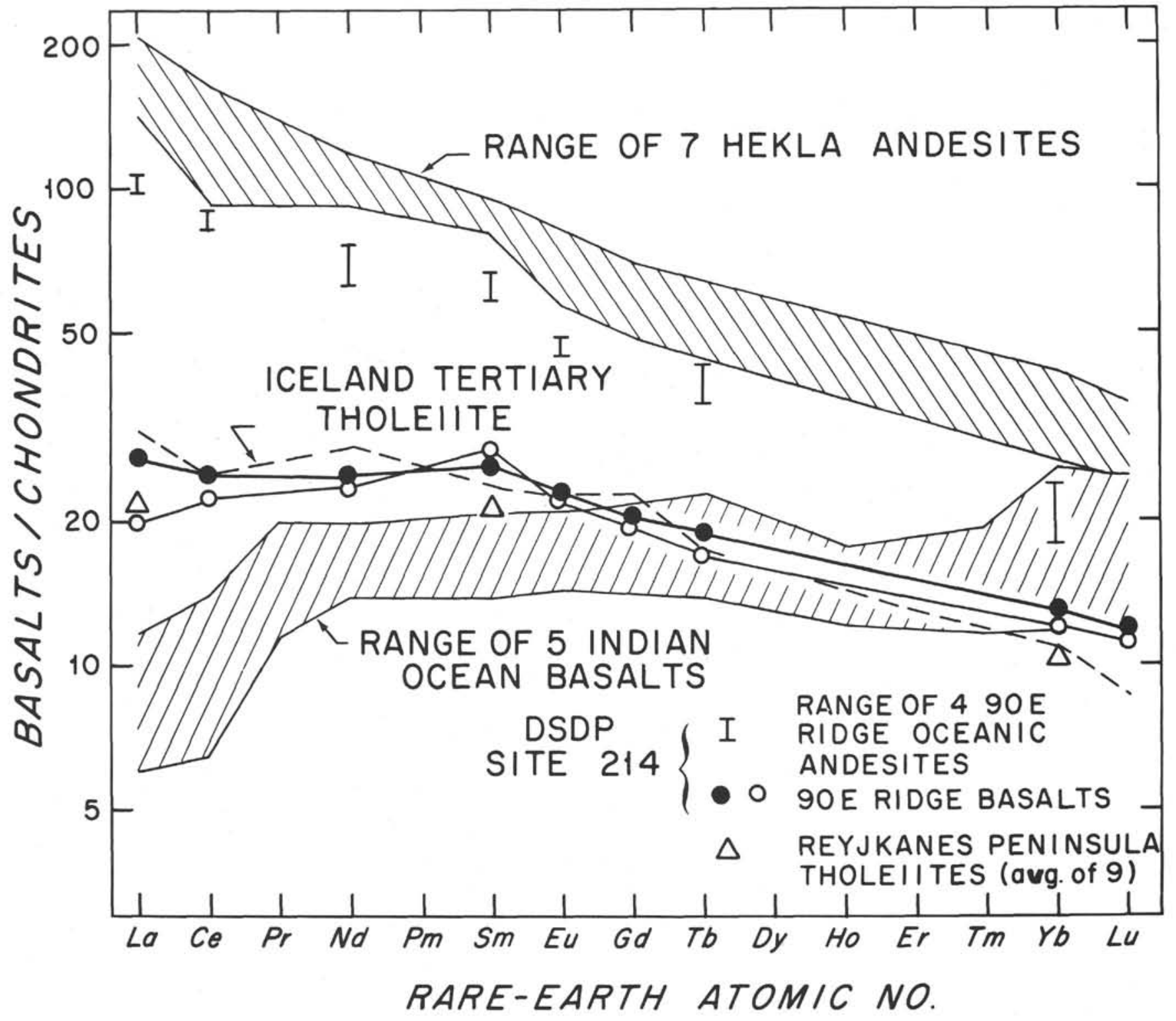

Figure 2. Rare-earth element comparison plot showing data for two Site 214 Ninetyeast Ridge basalts (J46 filled circle and J42 open circle) and the range for four Site 214 Ninetyeast Ridge andesites (J35, J37, J38, J40). Also shown is the range for seven Hekla andesites (unpublished), the range for four mid-Indian Ocean ridge basalts (Schilling, 1971), the average of nine Reykjanes Peninsula tholeiites (Schilling, in press), and the average of 11 analyses of tertiary Icelandic tholeiitic basalts (Haskin et al., 1971).

1973. Glassy abyssal basalts, Atlantic sea floor near St. Paul's Rocks: petrography and composition of secondary clay minerals: Geol. Soc. Am. Bull., v. 84, p. 703-716.

Schilling, J. G., 1971. Sea-floor evolution; rare-earth evidence: Phil. Trans. Roy. Soc. Lond. A, v. 268, p. 663-706.

, in press. Iceland mantel plume existence, and influence along the Reykjanes Ridge: geochemical evidence: Nature.

Taylor, S. R., Capp, A. C., Graham, A. L. and Blake, D. H., 1969. Trace element abundances in Andesites II. Saipan, Bougainville and Fiji: Contr. Min. Petrol., v. 12, p. 1-26.

Thompson, G., 1972. A geochemical study of some lithified carbonates from the deep-sea: Geochim. Cosmochim. Acta, v. 36 , p. 1237-1253.
Thompson, G. and Bankston, D. C., 1969. A technique for trace element analysis of powdered materials using the d.c. arc and photoelectric spectrometry: Spectrochim. Acta, v. 24B, p. 335-350.

Thompson, G. and Melson, W. G., 1970. Boron contents of serpentinites and metabasalts in the oceanic crust: implications for the boron cycle in the oceans: Earth Planet. Sci. Lett., v. 8, p. 61-65. 1972. The petrology of oceanic crust across fracture zones in the Atlantic Ocean: evidence of a new kind of sea-floor spreading: J. Geology, v. 80, p. 526-538.

Thorarinsson, S., 1967. Hakla and Kapla: In Iceland in Mid-ocean ridges, Bjornsson, S. (Ed.), Soc. Scient. Islandica, p. 190-199.

Upton, B. G. J. and Wadsworth, W. J., 1972. Aspects of magmatic evolution on Reunion Island: Phil. Trans. Roy. Soc. Lond. A, v. 271, p. 105-130. 
TABLE 5

Analyses of Oceanic Andesites, Site 214 Ninetyeast Ridge

\begin{tabular}{|c|c|c|c|c|c|c|}
\hline Core-Section & $48-1$ & $48-2$ & $48-2$ & $49-1$ & $50-1$ & $51-1$ \\
\hline Depth in Core $(\mathrm{cm})$ & $76-83$ & $9-13$ & $117-123$ & $137-144$ & $145-150$ & $108-114$ \\
\hline Lab No. & J33 & J35 & J37 & J38 & $\mathrm{J} 40$ & $\mathrm{~J} 41$ \\
\hline $\mathrm{SiO}_{2}$ & 56.69 & 55.70 & 54.59 & 57.41 & 55.70 & 51.34 \\
\hline $\mathrm{A}_{2} \mathrm{O}_{3}$ & 16.10 & 15.40 & 15.67 & 15.81 & 15.30 & 18.73 \\
\hline $\mathrm{Fe}_{2} \mathrm{O}_{3}$ & 2.88 & 3.11 & 2.42 & 2.83 & 2.91 & 3.80 \\
\hline $\mathrm{FeO}$ & 7.55 & 7.00 & 7.47 & 7.00 & 7.00 & 2.72 \\
\hline $\mathrm{MgO}$ & 2.57 & 2.40 & 2.60 & 2.32 & 2.30 & 1.02 \\
\hline $\mathrm{CaO}$ & 5.62 & 5.59 & 5.82 & 5.86 & 5.71 & 7.97 \\
\hline $\mathrm{Na}_{2} \mathrm{O}$ & 4.08 & 3.88 & 3.88 & 3.92 & 3.78 & 4.21 \\
\hline $\mathrm{K}_{2} \mathrm{O}$ & 1.56 & 1.55 & 1.27 & 1.58 & 1.49 & 1.83 \\
\hline $\mathrm{TiO}_{2}$ & 1.40 & 1.40 & 1.43 & 1.46 & 1.44 & 1.56 \\
\hline $\mathrm{P}_{2} \mathrm{O}_{5}$ & 0.56 & 0.63 & 0.68 & 0.65 & 0.66 & 0.80 \\
\hline Ignition loss & 1.22 & 1.15 & 1.99 & 1.18 & 1.42 & 5.06 \\
\hline B & $<2$ & $<2$ & $<2$ & $<2$ & $<2$ & $<2$ \\
\hline $\mathrm{Ba}$ & 640 & 600 & 530 & 590 & 530 & 780 \\
\hline Co & 41 & 40 & 34 & 44 & 38 & 25 \\
\hline $\mathrm{Cr}$ & $<5$ & $<5$ & $<5$ & $<5$ & $<5$ & $<5$ \\
\hline $\mathrm{Cu}$ & 3 & 2 & 1 & 3 & 2 & 1 \\
\hline $\mathrm{Ga}$ & 22 & 23 & 24 & 22 & 23 & 29 \\
\hline $\mathrm{Li}$ & 6 & 7 & 8 & 4 & 4 & 11 \\
\hline Mo & $<2$ & 3 & 3 & 3 & 5 & $<2$ \\
\hline $\mathrm{Ni}$ & $<5$ & $<5$ & $<5$ & $<5$ & $<5$ & $<5$ \\
\hline $\mathrm{Sr}$ & 800 & 625 & 615 & 615 & 580 & 1500 \\
\hline $\mathrm{V}$ & 40 & 40 & 40 & 40 & 35 & 70 \\
\hline $\mathrm{Y}$ & 63 & 67 & 73 & 62 & 62 & 85 \\
\hline $\mathrm{Zr}$ & 235 & 255 & 290 & 245 & 235 & 380 \\
\hline $\mathrm{U}^{\mathrm{a}}$ & 0.4 & 0.6 & 0.4 & 0.8 & 0.9 & 1.0 \\
\hline $\mathrm{Sc}^{\mathrm{b}}$ & & 17 & 15 & 17 & 17 & \\
\hline $\mathrm{Hf}^{\mathrm{b}}$ & & 8.7 & 7.8 & 8.1 & 8 & \\
\hline $\mathrm{Ta}^{\mathrm{b}}$ & & 10.4 & 7.4 & 10.3 & 11 & \\
\hline $\mathrm{La}^{\mathrm{b}}$ & & 30.8 & 34 & 33 & 33 & \\
\hline $\mathrm{Ce}^{\mathrm{b}}$ & & 85 & 73 & 78 & 73 & \\
\hline $\mathrm{Nd}^{\mathrm{b}}$ & & 461 & 38 & 41 & 44 & \\
\hline $\mathrm{Sm}^{\mathrm{b}}$ & & 10.9 & 11.8 & 11.3 & 11.1 & \\
\hline $\mathrm{Eu}^{\mathrm{b}}$ & & 3.35 & 3.02 & 3.21 & 3.1 & \\
\hline $\mathrm{Tb}^{\mathrm{b}}$ & & 1.98 & 1.57 & 1.76 & 1.9 & \\
\hline $\mathrm{Yb}^{\mathrm{b}}$ & & 4.85 & 3.66 & 4.46 & 4.6 & \\
\hline $\mathrm{Lu}^{\mathrm{b}}$ & & 0.97 & & 0.88 & 1.0 & \\
\hline $\mathrm{Th}^{\mathrm{b}}$ & & & & & 4.5 & \\
\hline
\end{tabular}

Note: See note, Table 1.

${ }^{a}$ Analyzed by fission track technique.

$\mathrm{b}_{\text {Analyzed by neutron activation. }}$ 
G. THOMPSON, W. BRYAN, F. FREY, C. SUNG

TABLE 6

Comparative Analyses of Andesites from Site 214, Ninetyeast Ridge, and Similar Rocks from Other Oceanic Regions

\begin{tabular}{|c|c|c|c|c|c|}
\hline & $\begin{array}{l}\text { Site }^{a} \\
214\end{array}$ & $\begin{array}{l}\text { Mugearite }^{\mathrm{b}} \\
\text { Reunion } \\
\text { Island }\end{array}$ & $\begin{array}{c}\text { Andesite } \\
\text { Tonga } \\
\text { Island } \\
\text { Arc }\end{array}$ & $\begin{array}{l}\text { Andesite }^{\mathrm{d}} \\
\text { Circum- } \\
\text { Pacific } \\
\text { Type }\end{array}$ & $\begin{array}{c}\text { Andesite } \\
\text { Hekla } \\
\text { Iceland }\end{array}$ \\
\hline $\mathrm{SiO}_{3}$ & 56.02 & 52.1 & 57.57 & 59.5 & 55.57 \\
\hline $\mathrm{Al}_{2} \mathrm{O}_{3}$ & 15.66 & 17.1 & 14.14 & 17.2 & 15.12 \\
\hline $\mathrm{Fe}_{2} \mathrm{O}_{3}$ & 2.83 & 2.0 & 3.60 & & 4.63 \\
\hline $\mathrm{FeO}$ & 7.20 & 8.7 & 8.62 & $6.10^{*}$ & 7.14 \\
\hline $\mathrm{MgO}$ & 2.44 & 2.6 & 3.29 & 3.42 & 2.32 \\
\hline $\mathrm{CaO}$ & 5.72 & 6.9 & 8.42 & 7.03 & 6.61 \\
\hline $\mathrm{Na}_{2} \mathrm{O}$ & 3.91 & 4.9 & 2.42 & 3.68 & 4.07 \\
\hline $\mathrm{K}_{2} \mathrm{O}$ & 1.49 & 2.4 & 0.70 & 1.60 & 1.30 \\
\hline $\mathrm{TiO}_{2}$ & 1.43 & 2.3 & 0.80 & 0.70 & 1.92 \\
\hline $\mathrm{P}_{2} \mathrm{O}_{5}$ & 0.64 & 0.7 & 0.12 & & \\
\hline $\begin{array}{l}\text { Ignition } \\
\text { loss }\end{array}$ & 1.39 & & & & \\
\hline B & $<2$ & & 18 & $<10$ & $<10$ \\
\hline $\mathrm{Ba}$ & 578 & 800 & 165 & 270 & 395 \\
\hline Co & 39 & & 31 & 24 & 9 \\
\hline $\mathrm{Cr}$ & $<5$ & 8 & 6 & 56 & $<2$ \\
\hline $\mathrm{Cu}$ & 2 & $<10$ & 215 & 54 & 10 \\
\hline $\mathrm{Ga}$ & 23 & & 19 & 16 & 25 \\
\hline $\mathrm{Li}$ & 6 & & & 10 & 20 \\
\hline Mo & 3 & & & & \\
\hline $\mathrm{Ni}$ & $<5$ & $<10$ & 9 & 18 & 7 \\
\hline $\mathrm{Sr}$ & 647 & 650 & 225 & 385 & 485 \\
\hline $\mathrm{U}$ & 0.6 & & & & \\
\hline V & 39 & 75 & 410 & 175 & 83 \\
\hline $\mathrm{Y}$ & 65 & 47 & 25 & 21 & 39 \\
\hline $\mathrm{Zr}$ & 252 & 390 & 40 & 110 & 450 \\
\hline
\end{tabular}

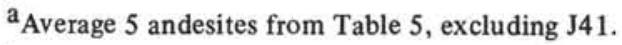

${ }^{b}$ Average 6 mugearites from Reunion Island, from Upton and Wadsworth (1972).

${ }^{c}$ Andesite, Late Island (111547-13), from Ewart et al. (in press).

d Average circum-Pacific andesite, from Taylor et al. (1969).

e Average 3 andesites Hekla, Iceland (USNM 112046, 112030, 112050), unpublished. 